\title{
Piotr Barczak
}

\section{Odmienność postrzegania} wartości dodanej dla firm i wartości dla klienta w łańcuchu dostaw

Wartość dodaną i wartość dla klienta należy rozpatrywać odmiennie $w$ łańcuchach dostaw, gdyż inne czynniki wywołują reakcje u przedsiębiorców, a inne u ostatecznych klientów. Wartość dla klienta stymulowana jest mocniej przez czynniki behawioralne niż wartość dodana. Zarządzający firmami biorą pod uwagę głównie czynniki ekonomiczne, a emocje mają dla nich mniejsze znaczenie. W takiej sytuacji, w zróżnicowany sposób można stosować mierniki w różnych częściach łańcuchów dostaw. Artykuł nawiązuje do nurtu ekonomii behawioralnej.

Odmienność ujmowania wartości dodanej w firmie i wartości dla klienta zauważono już na początku tworzenia koncepcji wartości. P. Drucker wskazywał, że cena jest składową wartości, a sama wartość w przypadku firm jest „różnicą między wpływami brutto danej firmy a sumą, którą zapłaciła ona za surowce i za usługi dostawców zewnętrznych”. W jego pierwszych tekstach pojawiają się też pojęcia wartości „u klienta” i osiąganej przez niego satysfakcji [Drucker, 1998]. W koncepcjach M.E. Portera przewaga konkurencyjna wynika z kreowania wartości firmy i wartości dla nabywcy. Zauważa również, że istnieje wartość konsumenta i wynika ona z podejmowanych przez gospodarstwo domowe działań i decyzji. $\mathrm{Na}$ użytkownika końcowego oddziałuje smak, wartości odżywcze, konsystencja, wygląd produktu, jego cena, dostępność, rozmiar opakowania. Z kolei w punkcie detalicznym wpływa na niego reklama, miejsce na półce sklepowej, promocja $\mathrm{w}$ sklepie i dostępność [Porter, 2006].

Już w początkowej fazie rozważań nad wartością dla klienta zauważono, że klienci postrzegają wartość w sposób subiektywny, a ważnymi aspektami z ich punktu widzenia był stracony czas, koszty poszukiwania produktów oraz koszty psychiczne [Zeithaml, 1988]. Ten punkt widzenia przyjęło wielu późniejszych autorów, m.in. P. Kotler, M.B. Holbrook czy R.B. Woodruff.

Poszukując sił napędowych wartości zwrócono uwagę na wielowymiarowość zagadnienia. Pojęcie to zaczęło się wyraźnie różnić od określenia - wartość dodana dla firmy. Wartość dla klienta rozumiano jako różnicę między łącznymi korzyściami osiąganymi przez klienta, a wszelkimi jego kosztami związanymi z zakupem. Brano pod uwagę elementy natury socjologicznej, psychologicznej i ekonomicznej. Równocześnie nastąpiła zmiana paradygmatu zarządzania łańcuchem dostaw. Ważną kwestią w naukach o łańcuchach dostaw stało się przesunięcie na drugi plan procesu wytwarzania produktów, a w miejsce tego znalazło się uznanie, że rynkowe elementy, w tym dokonanie płatności przez klientów, są kluczowymi w procesie wymiany. Można to uważać za 
punkt zwrotny w naukach o zarządzaniu [Krawczyk, 2011]. Siłą napędową działań w łańcuchach dostaw stał się natomiast popyt kreowany przez klientów [Rutkowski, 2005]. Dlatego rozpatrując łańcuchy dostaw nie zrezygnowano z uwzględnienia czynników behawioralnych. Stały się one jednak cechą immanentną związaną z ostatecznym klientem. Środowiska logistyczne, w tym J. Gattorna, w swoich pracach na temat łańcuchów dostaw stwierdził, że siłami napędzającymi łańcuchy dostaw są: odczuwanie, współpraca i relacje, intuicja, czucie i myślenie. Behawioralne zachowania klientów stały się źródłem funkcjonowania łańcuchów dostaw [Gattorna, 2013].

Istotnym elementem odróżniającym wartość dla klienta od wartości dodanej dla firmy są emocje. Klienci działają emocjonalnie. Wystarczy spojrzeć na paniczne artykuły medialne, na zachowania klientów w placówkach detalicznych w czasie promocji. Zupełnie odmienną sytuację zauważamy w przypadku powstawania wartości dodanej w firmach działających w łańcuchu dostaw. Bierze się w nich pod uwagę szybkość realizacji zamówień, marżę dystrybucyjną, niezawodność usług serwisowych oraz wsparcie w działaniach promocyjnych. W procesach decyzyjnych rozpatruje się niemal wyłącznie elementy jednowymiarowe o charakterze ekonomicznym. Emocje w decyzjach prezesów i właścicieli firm odgrywają zdecydowanie mniejszą rolę niż w przypadku klientów ostatecznych. Działania emocjonalne w zarządach firm świadczą wręcz o niskim profesjonalizmie biznesowym. Najtrwalsze $\mathrm{z}$ nich tworzone są w wyniku spokojnych i przemyślanych decyzji, gdy emocje osób zarządzających zostają stłumione. Potwierdziły to badania [Barczak, 2017].

\section{Wielowymiarowe elementy budowania wartości dla klienta}

Wielowymiarowość oddziaływań na wartość dla klienta jest znana od lat. Nie poznano jednak wszystkich czynników wpływających na zachowania konsumentów, gdyż przy ich rozpoznawaniu mamy do czynienia z szeregiem zagadnień dotyczących różnych dziedzin nauki, począwszy od medycyny, psychologii i wreszcie kończąc na zarządzaniu. Ważnymi składowymi mającymi związek z budowaniem wartości dla klienta $\mathrm{w}$ łańcuchach dostaw są satysfakcja i lojalność. Sprecyzowano natomiast definicję wartości dla klienta. Wywodzi się ona z nauk o marketingu i wskazuje, że jest to różnica pomiędzy całkowitą wartością produktu lub usługi dla klienta a kosztem, jaki musi on ponieść $\mathrm{w}$ związku z jego pozyskaniem [Kotler, 2005]. Dlatego przy analizie wartości dla klienta powinno się uwzględniać również emocje konsumenta. Są one ważnym czynnikiem odróżniającym wartość dla klienta od wartości dodanej dla firmy.

Próbę uszeregowania emocji przy rozpatrywaniu zagadnienia osiągania wartości dla klienta przeprowadzono w modelu Russella [Russell, 2008], w którym są one pogrupowane w oparciu o stopnie pobudzenia i przyjemności. Można je przedstawić w formie graficznej (rysunek 1). Stopień pobudzenia emocjonalnego odwzorowuje linia pionowa, a stopień przyjemności linia pozioma. W siatkę Russella - eksperymentalnie - można wkomponować skalę wartość dla klienta. W modelu Russella wydzielono pola emocjonalne między współrzędnymi. Górna lewa „ćwiartka” to stany emocjonalne związane ze stresem. Lewa dolna „ćwiartka” to stany depresji, na którą oddziałują elementy niskiego pobudzenia. W prawej części modelu, na klientów wpływają elementy przyjemności o różnej skali. Dlatego w górnej prawej „ćwiartce” są to stany pobudzenia, w dolnej prawej „ćwiartce” stany zadowolenia, na które oddziałują niskie stany pobudzenia.

Dodatkowo uwzględniono stany lojalności, które są powiązane $\mathrm{z}$ występowaniem satysfakcji. Ciągle nie wyjaśniono 


\section{Rysunek 1 Układ emocji, wartości dla klienta, satysfakcji oraz lojalności}

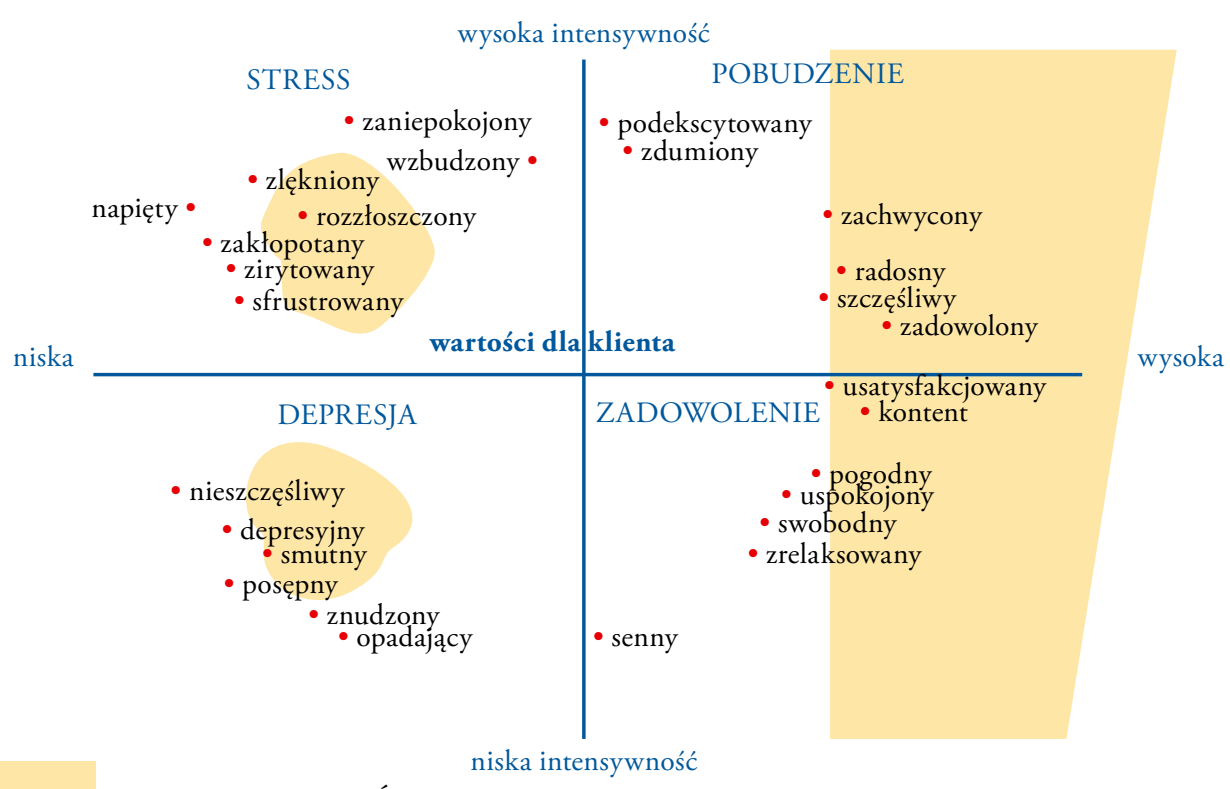

Źródło: opracowanie własne na podstawie: Russell [2008].

jednak, dlaczego występowanie satysfakcji nie zawsze wiąże się z lojalnością. Niekiedy lojalny klient jest niezadowolony i odwrotnie.

Eksperymentalny model przestrzenny, aby wykazać powiązanie emocji $\mathrm{z}$ wartością dla klienta, zmodyfikowano o występujące stany wartości dla klienta. $\mathrm{Na}$ linii poziomej przedstawiono osiąganą wartość dla klienta w ujęciu niska - wysoka. Takie ujęcie wartości powiązane jest z satysfakcją. Na linii pionowej wskazano na niską i wysoką intensywność wartości dla klienta. Intensywność rozumiana jest jako powiązanie natężenia występowania emocji i wartości. Model uzupełniono o powstającą strefę lojalności dla klientów.

Jeśli klient doświadcza stanu niskiej wartości dla klienta, objawiającej się przykrościami i małą satysfakcją w emocjonalnym stanie niskiego pobudzenia, to efektem jest specyficzna „depresja klienta”, a a tę „ćwiartkę" modelu charakteryzują określone negatywne zachowania (dolna lewa „ćwiartka” na rysunku 1). W takiej grupie można jednak spotkać lojalnych klientów, niekiedy znudzonych, ale z przyzwyczajenia lojalnych. Dlatego „pole lojalności”, wydzielone graficznie, ma charakter „wyspowy”.

Dostarczenie niskiej wartości dla klienta o wysokiej intensywności powoduje u konsumenta reakcję stresu (górne lewe pole). W tej „ćwiartce” modelu umieszczono zachowania klientów, którzy mogą być sfrustrowani i zirytowani, ale lojalni. „Pole lojalności” ma również charakter wyspowy.

Stany przyjemności i podniecenia, o dodatniej wartości dla klienta i wysokiej intensywności, generują pozytywne stany pobudzenia (górna prawa „ćwiartka"). W tej przestrzeni zawierają się stany zdumienia i zachwycenia. Na prawo (jednolite pole), wydzielono ciągłą strefę lojalności, która grupuje klientów szczęśliwych, radosnych i zachwyconych.

Dodatnia wartość dla klienta i niska intensywność wartości wywołuje emocjonalną senność, przejawiającą się biernością (dolna prawa „ćwiartka”). W takiej sytuacji również możemy mieć do czynienia z zadowoleniem, ale bez lojalności. To adwokaci firmy.

Emocje z biegiem czasu ulegają zanikowi, najprawdopodobniej dzieje się to 


\section{Rysunek 2 Krzywa lojalności}

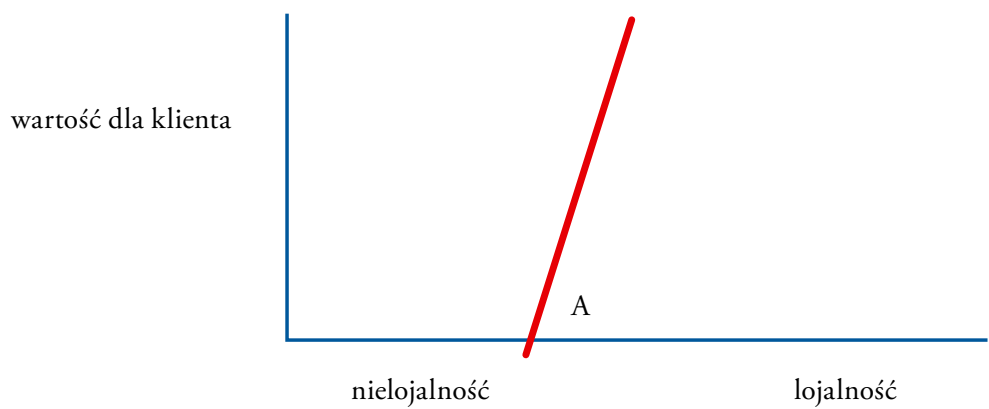

Źródło: opracowanie własne.

również z wartością dla klienta. Satysfakcja zanika, z czasem też lojalność [Urban, Siemieniako, 2008], a także wartość dla klienta. Nauki psychologiczne wskazują jednak, że człowiek potrzebuje ciągle nowych emocji w celu zachowania zdrowia [Adler, et. al, 2007]. Dodatkowo, powiązania lojalności i wartości dla klienta można opisać przy pomocy krzywej lojalności (rysunek 2). Lojalność kształtuje się dopiero powyżej pewnego stanu oznaczonego literą A, a wzrost wartości dla klienta nie jest proporcjonalny do wzrostu lojalności. Krzywa zachowuje się identycznie jak w przypadku szczęścia w koncepcji dobrostanu psychicznego. Większe bogactwo nie prowadzi wprost proporcjonalnie do większego szczęścia, dlatego krzywa ma inne nachylenie niż proporcjonalne.

Krzywa lojalności zostaje naniesiona na krzywą wartości będącą reakcją klienta na cenę (rysunek 3). Wartość krańcowa $\mathrm{w}$ relacji do ceny z biegiem czasu maleje. Każda następna cena dostarczona klientowi oddziałuje na niego przy coraz niższej jego satysfakcji (w górnym odcinku krzywa ma charakter opadający).

Równocześnie, pod kątem $45^{\circ}$, wyznaczono krzywą wartości $\mathrm{w}$ relacji do zadowolenia, a ponieważ zadowolenie jest miernikiem wartości, przyjęto proporcjonalną relację między nimi. Powyżej linii $45^{\circ}$ powstaje pole wartości dla klienta, istnieje również tego typu pole poniżej linii $45^{\circ}$, mimo że oddziałuje na nie niezadowolenie. Przecięcia krzywej lojalności z krzywą wartości ukazują „pola lojalności” przedstawione na rysunku 1 . Na przecięciach wartość dla klienta występuje wraz z lojalnością oraz satysfakcją lub jej brakiem. Rysunek wyjaśnia, dlaczego niezadowolony klient może być lojalny, w

\section{Rysunek 3 Krzywa wartości w relacji do oferowanej ceny}

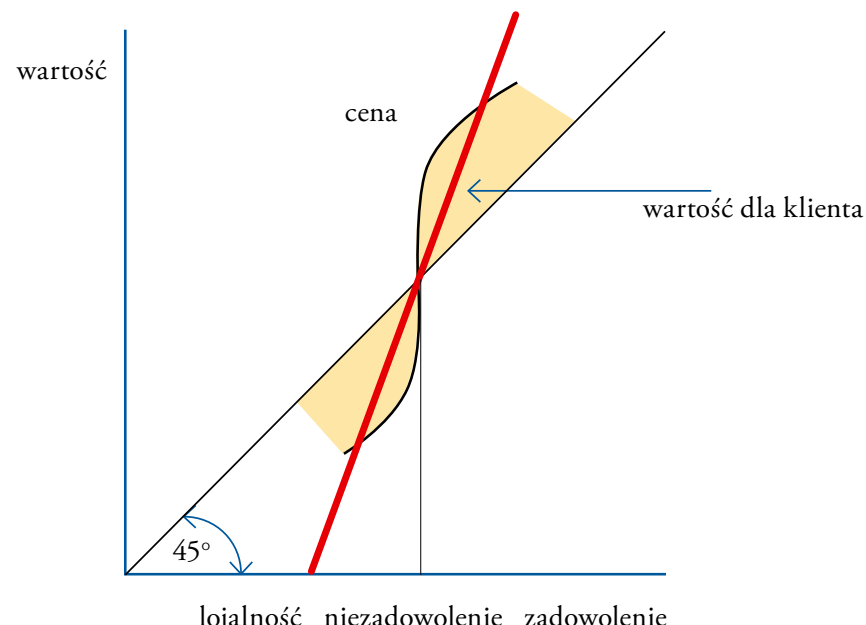


kontekście malejącej wartości dla klienta. Wartość dla przedsiębiorcy, jego lojalność i satysfakcja mogą jednak zachowywać się odmiennie, co wymaga dodatkowych badań i analiz.

\section{Jednowymiarowe czynniki budowania wartości dodanej}

Definicja wartości dodanej dla przedsiębiorstwa ciągle nie została ostatecznie i jednoznacznie sprecyzowana, mimo kilku prac, które poruszały ten temat. Według jednej z koncepcji, wartość dodana dla przedsiębiorstwa jest różnicą pomiędzy korzyściami dla przedsiębiorstwa względem kosztów ponoszonych przez przedsiębiorstwo. Wartość dodana w łańcuchu dostaw może też być rozumiana jako wartość, którą - w mniemaniu klienta (odbiorcy) - dostawca wnosi podczas transakcji. Z kolei w przypadku producenta jest nią wartość dodana do materiałów i innych nakładów ponoszonych $\mathrm{w}$ procesie produkcji, którą producent przekazuje dalej. Natomiast w przypadku firmy handlowej może ona wynikać z funkcjonalności, estetyki, organizacji czy też korzystnej lokalizacji punktów handlowych. Pojęcie wartości dodanej jest dość rzadko analizowane i ogranicza to jego rangę poznawczą. Ważne jest jednak, iż zauważono różnicę między wartością dodaną dla klienta (wartość dla klienta) i wartością dodaną dla przedsiębiorstwa [Matwiejczuk, 2006].

Jak zauważa S. Krawczyk, odmiennego wartościowania produktu dokonuje odbiorca produktu, a odmiennego producent. Dla klienta ważna jest użyteczność, a w obecnej erze globalizacji niezbędne są też dodatkowe atrybuty produktu ułatwiające jego przejęcie i użytkowanie. Czynną rolę w budowaniu wartości spełniają szybkie dostawy, ułatwienia w przyjęciu produktu, wygodne płatności, odpowiedni serwis, wreszcie łatwa utylizacja po wykorzystaniu. Jeśli klient jest z produktu niezadowolony, nie zaspoka- ja on zupełnie jego potrzeb, jest dla niego rzeczą zbędną, takiemu produktowi przypisać można zerową wartość ekonomiczną. Natomiast potencjalną wartość dodaną dla przedsiębiorstw jest różnica pomiędzy całkowitą wartością sprzedaży a poniesionymi kosztami. Dla producenta wartość produktu przedstawia cena, która powinna być wyższa od poniesionych kosztów. Dlatego też w procesie wytwarzania producent określa potencjalne możliwości produktu i jego potencjalną wartość, biorąc pod uwagę uwarunkowania rynkowe. Dopiero po odpowiednim zaspokojeniu potrzeby, potencjalna wartość dodana zamienia się w ekonomiczną wartość dodaną [Krawczyk, 2011].

Warto również poddać analizie wartość dodaną i wartość dla klienta w łańcuchu dostaw. W procesach zachodzących między firmami w łańcuchu dostaw, w bardzo niewielkim stopniu uwzględnia się emocje i inne czynniki wielowymiarowe jak szacunek, radość, duchowość, wiara, piękno czy estetyka. Są one zastępowane jednowymiarowymi czynnikami związanymi z ceną, kosztami produktów, jakością i innowacyjnością. Emocje występujące $\mathrm{w}$ procesie decyzyjnym w łańcuchach dostaw mogą w przedsiębiorstwach wywoływać ujemną wartość dodaną, gdyż często stają się przyczyną błędnych decyzji ekonomicznych. Dlatego w relacjach między firmami powinna być analizowana wartość dodana dla przedsiębiorstwa. W trakcie budowania wartości w łańcuchach dostaw, w relacjach zachodzących między firmami powstaje produkt w postaci „czystej”. Realizacja procesu, w wyniku którego on powstaje, wymaga terminowości dostaw, odpowiedniej polityki związanej z zapasami, dogodności związanych z płatnościami. W przebiegu tych procesów kluczowe znaczenie mają zagadnienia z zakresu logistyki, prawidłowo działających urządzeń w przedsiębiorstwach i właściwego zarządzania. Tego typu 


\section{Rysunek 4 Zróżnicowane oddziaływania czynników wielowymiarowych}

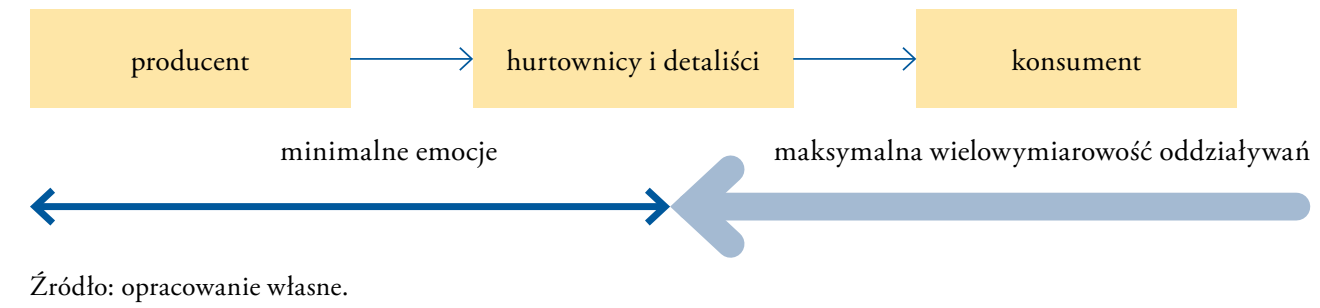

transakcje powodują powstawanie wartości dodanej produktu wzdłuż łańcucha dostaw.

\section{Dostosowanie metod pomiaru w lańcuchach dostaw}

Jak mierzyć wartość w łańcuchach dostaw, skoro ma ona odmienny charakter w przypadku firm i ostatecznych konsumentów? Zróżnicowane podejście zastosowano w Strategicznej Karcie Wyników, w której zintegrowano w jedną całość zestawy mierników z zakresu finansów, klientów, procesów wewnętrznych i rozwoju. Analogicznie można mierzyć wartość w łańcuchu dostaw, w którym biorą udział firmy i ostateczni klienci, różnicując metody pomiaru (rysunek 5).

W łańcuchach dostaw w części profesjonalnej, gdzie dochodzi do kontaktów między firmami, zaproponowano miernik o nazwie Ekonomiczna Wartość Dodana - EVA (Economic Value Added), a w przypadku ostatecznych klientów wskaźniki satysfakcji klientów, lojalności, utrzymania klientów oraz sprzedaży powtarzalnej.

\section{Rysunek 5 Model budowania wartości w łańcuchach dostaw}

FIRMY

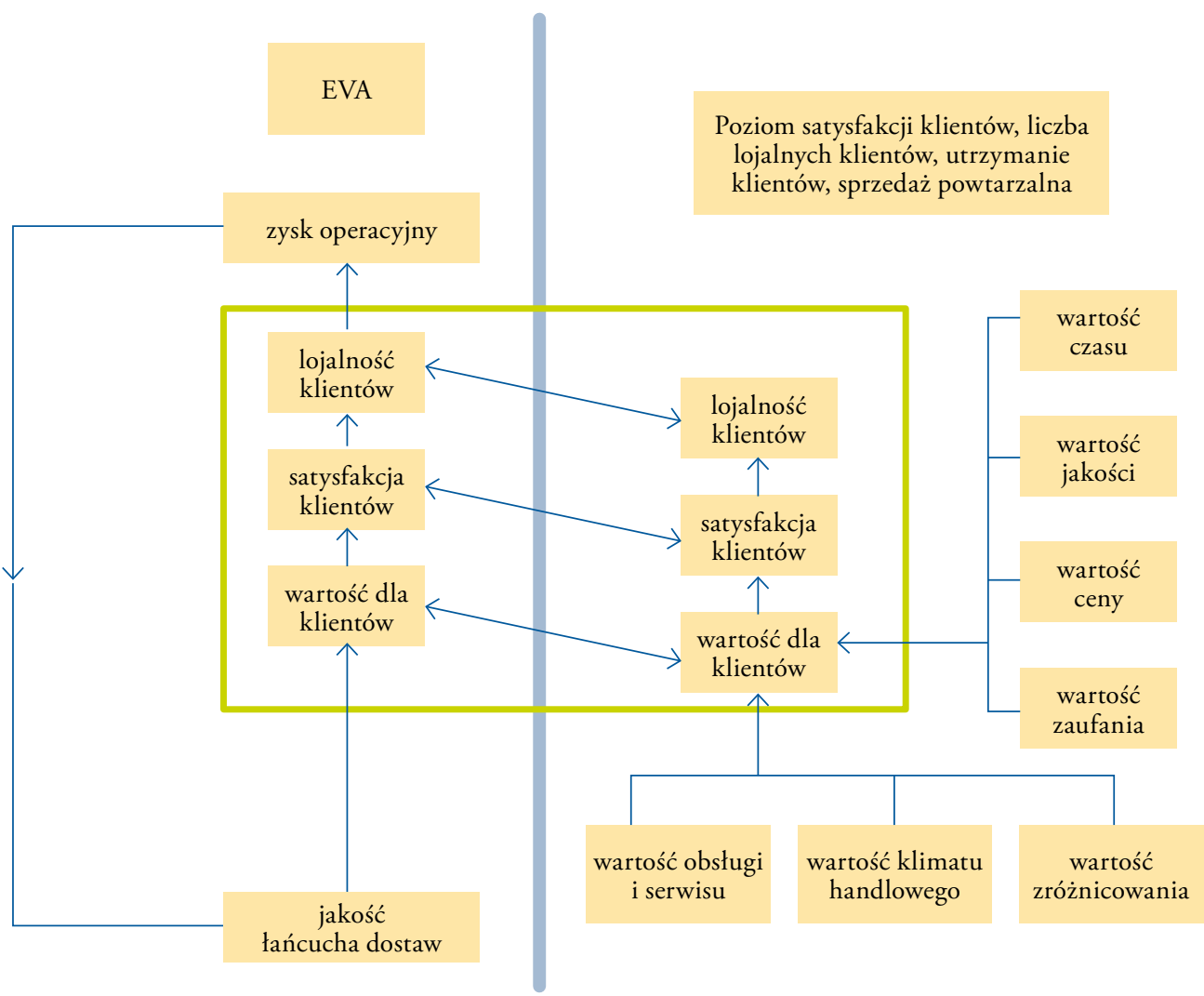


Dzięki temu ujęte zostają tak ważne determinanty oddziałujące na ostatecznego klienta jak lojalność i satysfakcja.

W przypadku ostatecznych klientów wskazane są odmienne metody badawcze niż w przypadku firm, w związku z występowaniem elementów wielowymiarowych, w tym emocji. Powszechnie wskazuje się na celowość badań ankietowych satysfakcji i lojalności klientów, powiązanych z występującą wartością dla klientów. Tego typu analizy w bardziej adekwatny sposób pozwalają zebrać dane związane $\mathrm{z}$ funkcjonowaniem ostatniego ogniwa łańcucha dostaw, jakim jest ostateczny klient. Warto dodać, że dla niego istotną rolę $\mathrm{w}$ postrzeganiu wartości dla klienta odgrywa również wartość serwisu, klimatu handlowego, w tym wyposażenie i wygląd placówki handlowej oraz zróżnicowanie oferty produktowej. Konsumenci biorą również pod uwagę wartość czasu, jakości, ceny i zaufania. Całokształt oddziałujących czynników decyduje o zachowaniu klientów i decyzjach występujących $\mathrm{w}$ procesie kreowania wartości $\mathrm{w}$ łańcuchach dostaw.

Do wykorzystania w łańcuchu dostaw w kontaktach między firmami zachęca prostota miernika EVA. To dość łatwe obliczenie trzech składowych: sprzedaży (sales), którą należy rozumieć, jako przychody wynikające z księgowego rachunku zysków i strat firm, następnie kosztów operacyjnych (operating costs), rozumianych, jako suma wszelkich ma- teriałów i kosztów produkcji, kosztów administracyjnych, kosztów ogólnych, kosztów kapitału ludzkiego, kosztów programów, w tym kosztów amortyzacji i podatków dochodowych od firm. Koszty te powinny również uwzględniać zużycie czynników materialnych, ale również niematerialnych, gdyż z biegiem czasu tracą one na wartości. Trzecim elementem jest koszt kapitału (capital costs), czyli całkowite środki finansowe otrzymane od kredytodawców, akcjonariuszy i własne, wykorzystywane do działalności firmy. Są one zainwestowane w zapasach, w należnościach, w środkach trwałych. Są to fizyczne pieniądze, które można zobaczyć i dotknąć, ulokowane w firmie w różnej formie [Stewart, 2013]. Miernik EVA jest na tyle elastyczny, że może być stosowany do oceny różnorodnych firm. Warto wspomnieć, że ma on ponad 160 odmian.

Wskazane w artykule czynniki powodują, że ostateczny klient i firmy powinny być odrębnie traktowane $\mathrm{w}$ łańcuchach dostaw. Inny ma charakter wartość dodana dla firm w profesjonalnych częściach, a inną wartość dla klienta w przypadku konsumenta. Klient stał się głównym podmiotem wymiany gospodarczej, a firmy muszą zaspokajać jego wszelkie potrzeby, dbając o racjonalizację swoich działań. Za tym nurtem myślenia muszą podążać mierniki i wskaźniki ekonomiczne, dzięki czemu lepiej zostanie odwzorowana ekonomiczna rzeczywistość łańcuchów dostaw.

\section{Bibliografia:}

1. Adler B.R., Rosenfeld L.B., Proctor R.F. II [2007], Relacje interpersonalne. Proces porozumiewania się, Poznań, Dom Wydawniczy Rebis, s. 217-247.

2. Barczak P. [2017], Kreowanie wartości w tańcuchu dostaw przez mate firmy niszowe, praca doktorska, Warszawa, Oficyna Wydawnicza SGH.

3. Drucker P.F. [1998], Praktyka zarządzania, AE w Krakowie, Czytelnik Nowoczesność, s. 72.

4. Gattorna J. [2013], Dynamiczne tańcuchy dostaw. Wartość tworzą ludzie, Suchy Las k. Poznania, Eurologistics, s. 227-228. 
5. Kotler Ph. [2005], Marketing, Wyd. I, Poznań, Dom Wydawniczy Rebis, s. 60.

6. Krawczyk S. (red.) [2011], Logistyka. Teoria i praktyka, Tom I, Warszawa, Difin, s. 103-106.

7. Matwiejczuk R. [2006], Zarządzanie marketingowo-logistyczne. Wartość i efektywność, Studia Ekonomiczne, Warszawa, C.H. Beck.

8. Porter M.E. [2006], Przewaga konkurencyjna, osiaganie i utrzymywanie lepszych wyników, Gliwice, Helion, s. 193.

9. Russell J.A. [1980], A Circumplex Model of Affect, "Journal of Personality and Social Psychology", Vol. 39(6), p. 1161-1178.

10. Rutkowski K. (red.) [2005], Logistyka dystrybucji. Specyfika. Tendencje rozwojowe. Dobre praktyki, Warszawa, Oficyna Wydawnicza SGH, s.74.

11. Stewart G.B. III [2013], Best-Practice EVA: The Definitive Guide to Measuring and Maximizing Shareholder Value, New Jersey, J. Wiley and Sons, p. 442-468.

12. Strauss B., Neuhaus P. [1997], The qualitative satisfaction model, "International Journal of Service Industry Management”, Vol. 8(3), MCB University Press, p. 236-248.

13. Urban W., Siemieniako D. [2008], Lojalność klientów. Modele, motywacje, pomiar, Warszawa, PWN, s. 35 .

14. Zeithaml V.A. [1988], Consumer Perceptions of Price, Quality and Value: A Means-End Model and Synthesis of Evidence, "Journal of Marketing”, Vol. 52, p. 2-22.

Dr inż. Piotr Barczak, Partner Instytutu Przedsiębiorstwa SGH, prezes P.H. Royal sp. z o.o. 